\title{
Epidemiological Study of Hepatitis A Virus and Hepatitis E Virus Infection in Patients Presenting with Acute Viral Hepatitis
}

\author{
Sarita Netra*, Rameshwari Bithu and Rakesh K. Maheshwari \\ Department of Microbiology, Sawai Man Singh Medical College and Attached Hospitals, \\ Jaipur, Rajasthan, India \\ *Corresponding author
}

\section{A B S T R A C T}

\begin{tabular}{|c|}
\hline Keywords \\
\hline $\begin{array}{l}\text { Acute viral hepatitis, } \\
\text { Hepatitis A, Hepatitis E, } \\
\text { Seroprevalence, Seasonal } \\
\text { variation, Hepatic } \\
\text { enzymes }\end{array}$ \\
\hline Article Info \\
\hline $\begin{array}{l}\text { Accepted: } \\
10 \text { April } 2018 \\
\text { Available Online: } \\
10 \text { May } 2018\end{array}$ \\
\hline
\end{tabular}

Hepatitis A virus (HAV) and hepatitis E virus (HEV) both are transmitted through the fecal-oral route and cause self-limiting acute viral hepatitis, and poses a major public health problem in India. This study was undertaken to determine prevalence of HAV and HEV in patients presenting with acute viral hepatitis and to study its seasonal trend. A retrospective study conducted in Department of Microbiology, SMS Medical College and attached Hospitals, Jaipur, Rajasthan. A total of 1751 serum samples of suspected patients of HAV and HEV tested for IgM HAV and IgM HEV antibody respectively using ELISA method. Seroprevalence of HAV and HEV was $8.03 \%$ and $21.94 \%$ respectively and both affected males more than females. HAV infection was more common in young children while HEV infection was more in adults. HAV and HEV infection has a seasonal trend having highest infection rate in summer and monsoon. Health and civic authorities should make an effort to increase the awareness among general public, to facilitate the timely preparation and make necessary arrangement for efficient response to encounter outbreak or epidemic, thus reduce morbidity, mortality and economic burden.

\section{Introduction}

Hepatitis A virus (HAV) and hepatitis E virus (HEV) are acquired by consumption of contaminated food and water through the fecal-oral route and cause self-limiting acute hepatitis. HAV and HEV both are endemic and a major health challenge in developing countries like India where conditions of hygiene and sanitation are poor.

Globally, an estimated 1.4 million cases of hepatitis A virus infection occur annually (WHO, 2000). HAV is the most common cause of acute viral hepatitis in children of 1-3 years age group (Nandi B et al., 2009). However, there has been a gradual upward shift in the average age of acquiring the HAV infection from early childhood to adulthood in different parts of the world (Mathur et al., 2008).

Hepatitis $\mathrm{E}$ is found worldwide, but the prevalence is highest in East and South Asia (NCDC, 2014). In areas with high disease endemicity, symptomatic infection is most common in young adults aged 15-40 years. In these areas, although infection does occur in 
children, they often have either no symptoms or develop subclinical illness. Every year, there are an estimated 20 million HEV infections worldwide, leading to an estimated 3.3 million symptomatic cases of hepatitis E.WHO estimates that hepatitis $\mathrm{E}$ infection caused approximately 44,000 deaths in year 2015 (WHO, 2017).

Outbreaks of HAV and HEV infection occur following monsoon rain, heavy flooding or massive uptake of untreated sewage into city water treatment plant. Hence the present study was undertaken to determine the prevalence of $\mathrm{HAV}$ and $\mathrm{HEV}$ in patients presenting with acute viral hepatitis and to study its seasonal trend at tertiary care hospital, Jaipur, Rajasthan.

\section{Materials and Methods}

It was a retrospective study conducted over a period of one year (July 2016 to June 2017) in the Department of Microbiology, SMS Medical College and attached Hospitals, Jaipur, Rajasthan. The study population included individuals of all age group who were suspected of acute viral hepatitis. Both in-door and out-door patients were included in the study. A total of 1751 serum samples of suspected patients of HAV and HEV analysed for IgM $\mathrm{HAV}$ and $\mathrm{IgM} \mathrm{HEV}$ antibody respectively using ELISA method. The demographic and clinical variables were recorded on a predesigned proforma. It included age, sex, residential address, symptoms of acute viral hepatitis. Laboratory data including levels of serum amino transferase (AST and ALT), alkaline phosphatase (ALP), and GGT (gammaglutamyl transpeptidase) were also collected.

\section{Results and Discussion}

In our study out of total 1751 serum samples, 908 serum samples were tested for IgM HAV and 843 serum samples were tested for IgM HEV. Of these 908 suspected HAV cases, IgM antibodies were detected in $73(8.03 \%)$ serum samples. Among 843 suspected HEV cases, 185 (21.94\%) serum samples were positive for $\operatorname{IgM}$ antibodies. Both HAV and HEV positivity was significantly high among males in comparison to females (Table 1).

The cases were classified according to their age groups into 2-12 years, 13-20 years, 2140 years, 41-60 years and >60 years. HAV infection was seen in all age group and it was more prevalent in the age group between 2 to 12 years. HEV infection was also seen among all age group and maximum prevalence in the age group 21-40 years (Table 2).

In IgM HAV positive patients elevated levels of AST (aspartate aminotransferase), ALT (alanine aminotransferase), ALP (alkaline phosphatise) and GGT (gamma-glutamyl transpeptidase) was seen in $71.23 \%, 79.45 \%$, $84.93 \%$ and $75.34 \%$ cases respectively, while among IgM HEV positive patients it was found in $89.72 \%, 77.29 \%, 82.16 \%$ and $74.59 \%$ cases respectively (Table 3 ).

There was no significant difference of HAV and HEV infection rate among rural and urban area (Table 4).

Maximum positive cases of HAV and HEV were found in from month April to September as summer and rainy season (Figure 1).

Hepatitis A virus (HAV) and Hepatitis E virus (HEV) both are enterically transmitted. The majority of HAV and HEV outbreaks might be explained by the lack of enough sewage and sanitation systems, defecation in open fields, which can contaminate surface drinking water source. Hepatitis A infection during childhood often is asymptomatic and unrecognized, and typically confers lifelong immunity. With increasing age at time of 
infection, symptomatic cases become more common. With improved hygiene and sanitation reflecting India's growing economy, more children might escape childhood HAV infection and remain susceptible to infection during adolescence and adulthood (Mathur, 2008).

HEV is the most important cause of epidemic acute viral hepatitis, though HAV is common among children. Most acute liver failures diagnosed in India are attributable to HEV, and HEV is the most severe and common cause of acute viral hepatitis during pregnancy (NCDC, 2014).
In our study prevalence of HAV and HEV was $8.03 \%$ and $21.94 \%$ respectively; in viral hepatitis surveillance- India (20112013)599605 cases tested for HAV, 7.4\% were positive, and among 187040 samples tested for HEV, $10.4 \%$ were positive (Kumar et al., 2015). In study by Radhakarishnan et al., prevalence of HAV and HEV was $13.3 \%$ and $17.3 \%$ respectively, while in other study by Arora et al., it was $19.31 \%$ and $78.78 \%$ (Radhakrishnan et al., 2000; Arora et al., 2013). A comparatively lower HAV prevalence may be due to improved living standards environmental hygiene and increasing Hepatitis A immunization.

Table.1 Sex distribution of HAV and HEV infection in patients presenting with acute viral hepatitis

\begin{tabular}{|c|c|c|c|}
\hline & \multicolumn{2}{|c|}{ Number of cases (\%) } & \multirow{2}{*}{ P value } \\
\hline HA V & Male & Female & \\
\hline HEV & $52(71.2 \%)$ & $21(28.8 \%)$ & 0.001 \\
\hline
\end{tabular}

Table.2 Age distribution of HAV and HEV infection in patients presenting with acute viral hepatitis

\begin{tabular}{|l|c|c|}
\hline \multirow{2}{*}{ Age group (years) } & \multicolumn{2}{|c|}{ Number of cases } \\
\cline { 2 - 3 } & HAV & HEV \\
\hline $\mathbf{2 - 1 2}$ & $42(57.53 \%)$ & $2(1.08 \%)$ \\
\hline $\mathbf{1 3 - 2 0}$ & $16(21.91 \%)$ & $30(16.21 \%)$ \\
\hline $\mathbf{2 1 - 4 0}$ & $12(16.43 \%)$ & $11461.62 \%)$ \\
\hline $\mathbf{4 1 - 6 0}$ & $2(2.73 \%)$ & $29(15.67 \%)$ \\
\hline$>\mathbf{6 0}$ & $1(1.36 \%)$ & $10(5.40 \%)$ \\
\hline
\end{tabular}

Table.3 Elevated liver enzymes in IgM HAV and IgM HEV antibody positive patients

\begin{tabular}{|l|c|c|}
\hline \multirow{2}{*}{ Liver enzymes } & \multicolumn{2}{|c|}{ Number of cases (\%) } \\
\hline AST & HAV & HEV \\
\hline ALT & $52(71.23 \%)$ & $166(89.72 \%)$ \\
\hline ALP & $58(79.45 \%)$ & $143(77.29 \%)$ \\
\hline GGT & $62(84.93 \%)$ & $152(82.16 \%)$ \\
\hline
\end{tabular}


Table.4 Prevalence of HAV and HEV in rural and urban area

\begin{tabular}{|l|c|c|}
\hline \multirow{2}{*}{} & \multicolumn{2}{|c|}{ Number of cases (\%) } \\
\hline HAV & Urban & Rural \\
\hline HEV & $38(52 \%)$ & $35(48 \%)$ \\
\hline
\end{tabular}

Fig.1 Seasonal variation of IgM HAV and IgM HEV antibody positive patients

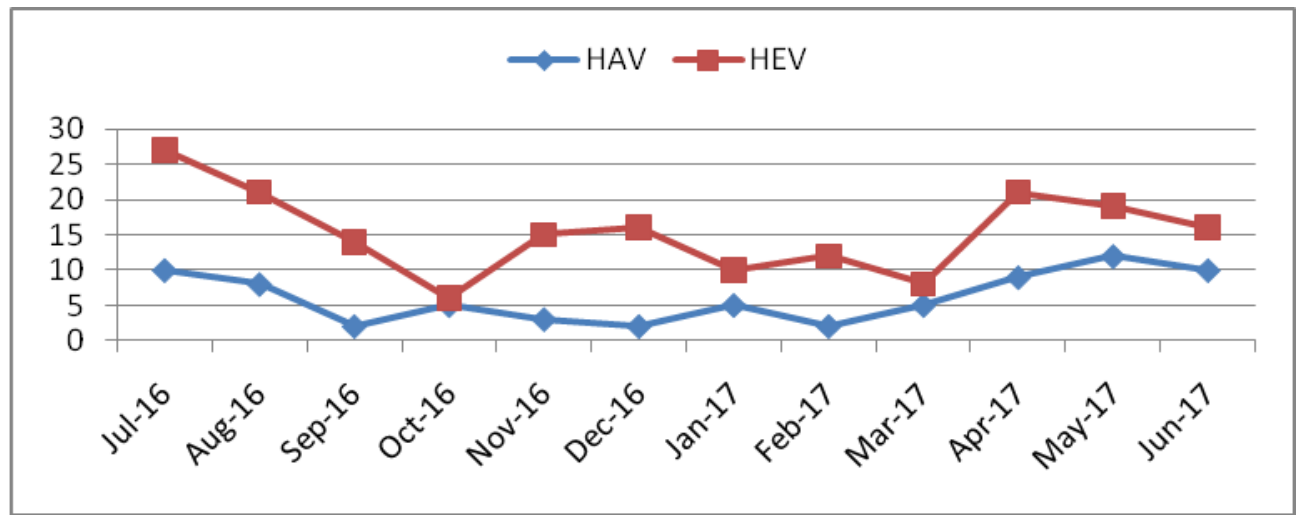

HAV infection was more common in young children (2-12 years) while the prevalence of HEV infection was more in adults (21-40 years) in comparison to children ( $<20$ years).

Other Indian authors also observed the similar finding (Chandra et al., 2012; Ren et al., 2017).

Prevalence of both HAV and HEV was higher in males than in females, this finding is consistent with other studies (Joon et al., 2015; Al-Naaimi et al., 2012; Kamal et al., 2010).

It could be because men have more exposure to outside food and drinking material for their professional purpose and social activities.

In this study there was no significant difference in occurrence of HAV and HEV among rural and urban area, while according to viral hepatitis surveillance- India (20112013) two-thirds of outbreaks were reported from rural areas (Kumar et al., 2015).
The present study has shown HAV and HEV infection has a seasonal trend having maximum positive cases in summer and monsoon that is April to September. Similarly Kumar et al., in viral hepatitis surveillanceIndia (2011-2013) observed 17\% increase in the total number of reported hepatitis cases during June- September, and laboratoryconfirmed HAV cases followed the same seasonal trend with an average increase of 18\% (Kumar et al., 2015). Joon et al., reported that HAV and HEV both were seen to be prevalent all around the year with predominance seen towards the end of monsoons and beginning of winters and also a peak rise of HEV during beginning of rainy season (Joon et al., 2015). Seasonal variation in transmission of acute viral hepatitis, possibly related to mixing of contaminated soil into wells and rivers during periods of heavy rains or floods (NCDC, 2014).

Prevention is the most effective approach against acute viral hepatitis. At the community level, transmission of HAV and 
HEV can be reduced by: maintaining quality standards for public water supplies and establishing appropriate sewage disposal systems. On an individual level, infection risk can be minimized by: maintaining hygienic practices such as hand-washing with clean water, particularly before handling food and avoiding consumption of water and/or food of unknown purity.

Inclusion of hepatitis A vaccine in childhood immunization programs should be considered to reduce the public health burden of hepatitis in India. In 2011, a vaccine to prevent hepatitis $E$ virus infection has been licensed in China. It has not yet been approved in other countries (WHO, 2017).

HAV and HEV infection should be considered as an etiology of acute infectious viral hepatitis, showing a seasonal trend having maximum positive cases in summer and monsoon that is April to September, as this infection is acquired through feco-oral route.

It is suggested that health and civic authorities should make an effort to increase the awareness among general public, to facilitate the timely preparation and make necessary arrangement for efficient response to encounter outbreak or epidemic, thus reduce morbidity, mortality and economic burden.

\section{References}

Al-Naaimi AS, Turky AM, Khaleel HA, Jalil RW, Mekhlef OA, Kareem SA, et al., 2012. Predicting acute viral hepatitis serum markers (A and E) in patients with suspected acute viral hepatitis attending primary health care centers in Baghdad: a one year cross-sectional study. Global journal of health science. Sep; 4(5): 172.
Arora D, Jindal N, Shukla RK, Bansal R. 2013. Water borne hepatitis A and hepatitis $\mathrm{E}$ in Malwa region of Punjab, India. J Clin Diagn Res.7: 2163-6.

Chandra NS, Sharma A, Rai RR, Malhotra B. 2012. Contribution of hepatitis $E$ virus in acute sporadic hepatitis in North Western India. Indian J Med Res. 136: 477-82.

Joon A, Rao P, Shenoy SM, Baliga S. 2015. Prevalence of Hepatitis A virus (HAV) and Hepatitis E virus (HEV) in the patients presenting with acute viral hepatitis. Indian journal of medical microbiology. Feb 1; 33(5): 102.

Kamal SM, Mahmoud S, Hafez T, EL-Fouly R. 2010. Viral hepatitis A to E in South Mediterranean countries. Mediterranean journal of hematology and infectious diseases. 2(1).

Kumar T, Shrivastava A, Kumar A, Laserson KF, Narain JP, Venkatesh S, et al., 2015Morbidity and mortality weekly report Vol. 64 / No. 28 July 24.

Mathur P, Arora NK. 2008. Epidemiological transition of hepatitis a in India: Issues for vaccination in developing countries. Indian J Med Res. 128: 699-704.

Nandi B, Hadimani P, Arunachalam R, Ganjoo RK. 2009. Spectrum of acute viral hepatitis in Southern India. Med J Armed Forces India. 65: 7-9.

NCDC Newsletter. Vol 3. Issue 1; JanuaryMarch, 2014. p. 1.

Radhakrishnan S, Raghuraman S, Abraham P, Kurian G, Chandy G, Sridharan G. 2000. Prevalence of enterically transmitted hepatitis viruses in patients attending a tertiary - Care hospital in South India. Indian J Pathol Microbiol; 43: 433-6.

Ren X, Wu P, Wang L, Geng M, Zeng L, Zhang J, et al., 2017. Changing epidemiology of hepatitis A and hepatitis E viruses in China, 1990- 
2014. Emerging infectious diseases. World Health Organization. www.who.int/ Feb; 23(2):276.

World Health Organization. Hepatitis A mediacentre/factsheets/fs280/en(last updated July 2017). vaccines: WHO position paper. Wkly Epidemiol Rec 2000; 75: 38-44

\section{How to cite this article:}

Sarita Netra, Rameshwari Bithu and Rakesh K. Maheshwari. 2018. Epidemiological Study of Hepatitis A Virus and Hepatitis E Virus Infection in Patients Presenting with Acute Viral Hepatitis. Int.J.Curr.Microbiol.App.Sci. 7(05): 899-904.

doi: https://doi.org/10.20546/ijcmas.2018.705.109 